Pak. J. Commer. Soc. Sci.

2012 Vol. 6 (2), 231-241

\title{
An Examination of Malaysia's Structural Breaks Vis-À-Vis Japan and the USA
}

\author{
Md. Wahid Murad \\ Lecturer, International Business Discipline, Business School, The University of Adelaide, \\ North Terrace Campus, Adelaide, South Australia, Australia. \\ E-mail: wahid.murad@adelaide.edu.au \\ Md. Mahadi Hasan \\ Senior Lecturer in Finance, School of Business, Green University of Bangladesh, \\ 220/D, Begum Rokeya Sarani, Dhaka-1207, Bangladesh. \\ E-mail: mahadihasan15@yahoo.com \\ Muhammad Shoeb-Ur-Rahman (Corresponding Author) \\ Lecturer in Management, School of Business, Green University of Bangladesh, \\ 220/D, Begum Rokeya Sarani, Dhaka-1207, Bangladesh. \\ E-mail: shoeb_mgt@yahoo.com \\ Md. Mahmudul Alam \\ Institute for Environment and Development, National University of Malaysia, \\ 43600 UKM, Bangi, Selangor Darul Ehsan, Malaysia. \\ E-mail: rony000@gmail.com
}

\begin{abstract}
This paper primarily examines whether Malaysia has had experienced any structural breaks in comparison with its main two trading partners, namely the USA and Japan in 1970s, 1980s, 1990s and 2000s. It also discusses the implications of such structural breaks to Malaysia's economic globalization at the international level. Using some econometric and statistical tools such as the ADF test, transformed lag equation, Chow Breakpoint test, and CUSUM test, the study reveals that only at $1 \%$ level of significance income ratio of Japan and Malaysia has had experienced structural breaks in terms of GDP during the periods 1980s, 1990s, and 2000s. In respect of GNI, the study reveals that only at 5\% level of significance their income ratio has had experienced structural breaks during these periods. The study further reveals that income ratio of the USA and Malaysia does not have any structural break both in respect of GNI and GDP.
\end{abstract}

Keywords: Structural breaks, Income ratio, Economic globalization, Income Convergence

\section{Introduction}

Malaysia formally started its industrialization journey in 1957 and proceeded phase by phase through the road map of development to realize its vision of becoming a 'fully developed' nation by 2020. Its development process follows the usual pattern that starts with the import-substitution based industrialization followed by export oriented 
industrialization and finally ends with technology-intensive high-value adding industrialization. However, globalization of its economy effectively started from 1970 with the program of export oriented industrialization added with industrial and social restructurings. Its industrialization and globalization program is characterized by unique features. 'Look east' and 'Malaysia-centric' autonomous identity themes are its mastermind and hardcore, and the free trade zone (FTZ) and economic development corridor (EDC) schemes are its cornerstones. With these unique features it has become known as a 'Malaysia model of economic development and globalization'.

Malaysia's industrialization and globalization approach is a strategy of growth with equity. It can be best described as a strong market embedded into a strong government and is driven by Malaysia's vision of becoming a fully developed and industrialized knowledge-based nation by the year 2020. It is a highly target oriented phase by phase approach strictly monitored and modified as necessary by compromising efficiency for effectiveness. Fostering national unity and growth with socio-economic justice through broader quantitative and qualitative participation of all groups of people at all levels of activities are the hardcore and touchstones of the approach and its tools and strategies. It is guided by long-term plans such as New Economic Policy, Outline Perspective Plans, National Development Policy, various Industrial and Knowledge-based Master Plans, etc. and is pursued through medium-term operational plans such as five-year Malaysia plans. In 1991 Malaysia formally articulated its vision as a blueprint of national development over a period of thirty years under the name Vision 2020, to transform it finally from a developing to a fully developed nation.

During the import substitution phase (1957-1969) tax exemption as an incentive was given under the Pioneer Industries Ordinance 1958 to encourage local and foreign firms to establish industries in the country. Under Investment Incentive Act 1968 the tax relief period was extended beyond 5 years. Certain 'infant industries' were given protection through import tariff and quota by Tariff Advisory Board and Federal Industrial Development Authority (FIDA).

During the most challenging long period of globalization through export oriented industrialization (1970-1990) all the plans and policy actions and institutions were geared to achieve the national objectives of economic growth with distributive justice, bring about social restructuring through reduction in economic disparity among the Malay, Chinese, and Indian ethnic groups, eradicate poverty, and promote national unity. As a result, in many ways and in many cases intensive government interventions were necessary to ensure increased participation of the Malay ethnic community at all levels of economic activities to enable them increase their wealth sharing and to reduce foreigners' equity ownership. Malays are the Bumiputera i.e., legal land-owners of the country; but they were far behind the non-Bumiputera (Chinese and Indian communities) and foreign investors in respect of ownership of national wealth. In 1970 their equity ownership was only a meager 2.4\%. Special state-owned companies under the State Economic Development Corporation (SEDCs) were set up to promote and serve Bumiputera entrepreneurs. In addition, government encouraged and pushed non-Bumiputera and foreign investors to form joint-venture companies with Bumiputera. This was a period of serious challenges and achievements. This study, however, is an effort to examine whether Malaysia has had experienced any structural breaks in comparison with its main two trading partners, namely the USA and Japan in 1970s, 1980s, 1990s and 2000s. It 
also discusses the implications of such structural breaks to Malaysia's economic achievement at the national level and its economic globalization at the international level.

\section{Significant Economic Achievements}

Economic globalization in Malaysia increased steadily under its economic development and industrialization strategy during 1970-2007. The index level of Malaysia's economic globalization increased from 63.00 in 1970 to 78.03 in 2009 placing the country at $34^{\text {th }}$ position among the world's 208 countries (KOF Index of Globalization 2009). From the context of national macroeconomic indicators Malaysia has had made significant and commendable achievements during the study period. During 1970 - 2007 per capita real gross national income (GNI) increased from $\$ 1,110$ to $\$ 5140$ with an average annual growth rate of 5\% (UN Online Database 2009), unemployment rate dropped from $8 \%$ in 1970 to 3.1\% in 2008 (Index Mundi 2009, International Labor Organization 2003, Ming Yu 2008), inflation rate dropped from 4.49\% in 1975to 2\% in 2007 (Ming Yu, 2008), foreigners' share of equity capital decreased from $63.4 \%$ in 1970 to $28.8 \%$ in 2004 (Malaysia 1996 \& Malaysia 2001), poverty rate decreased from $52.4 \%$ in 1970 to $3.6 \%$ in 2007 (Malaysia 2006 with a projection for total poverty in 2010 is $2.8 \%$, which was done recently by Economic Planning Unit, Prime Minister's Department, Malaysia). At the level of international competitiveness, however, Malaysian economy maintained a steady improvement moving from $40^{\text {th }}$ in 1980 to $21^{\text {st }}$ position in 2007 in terms of global industrial performance/competitiveness ranking (United Nations Industrial Development Organization 2004 \& World Economic Forum 2008). This may suggest that globalization has created an attractive and efficient industrial environment and caused transfer of technology in management, process, and products to increase economy's competitiveness and performance level.

\section{Extent of and Method for Examining Structural Breaks}

Observations from available literatures reveal that during 1970s, 1980s, and 1990s there were at least three structural breaks in the economies of Malaysia, Japan, and the United States of America. In order to test whether the income ratios of these three economies have had really experienced such breaks during the aforesaid periods, the following four equations have been developed and then transformed them in the form of lag as shown in next section.

$$
\begin{aligned}
& \Delta \ln \mathrm{Y}_{\mathrm{t}}=\alpha+\beta_{1} \ln \mathrm{T}+\beta_{2} \ln \mathrm{Y}_{\mathrm{t}-1}+\sum_{k=1}^{n} \delta K \Delta \ln \mathrm{Y}_{\mathrm{t}-\mathrm{k}}+\varepsilon \\
& \Delta \ln \mathrm{Y}_{2 \mathrm{t}}=\alpha+\beta_{1} \ln \mathrm{T}+\beta_{2} \ln \mathrm{Y}_{2 \mathrm{t}-1}+\sum_{k=1}^{n} \delta K \Delta \ln \mathrm{Y}_{2 \mathrm{t}-\mathrm{k}}+\varepsilon \\
& \Delta \ln \mathrm{Y}_{3 \mathrm{t}}=\alpha+\beta_{1} \ln \mathrm{T}+\beta_{2} \ln \mathrm{Y}_{3 \mathrm{t}-\mathrm{t}}+\sum_{k=1}^{n} \delta K \Delta \ln \mathrm{Y}_{3 \mathrm{t}-\mathrm{k}}+\varepsilon \\
& \Delta \ln \mathrm{Y}_{4 \mathrm{t}}=\alpha+\beta_{1} \ln \mathrm{T}+\beta_{2} \ln \mathrm{Y}_{4 \mathrm{t}-\mathrm{t}}+\sum_{k=1}^{n} \delta K \Delta \ln \mathrm{Y}_{4 \mathrm{t}-\mathrm{k}}+\varepsilon
\end{aligned}
$$

Where, $\mathrm{Y}_{\mathrm{t}}=$ USA per Capita Real GNI / Malaysia per Capita Real GNI, $\mathrm{Y}_{2 \mathrm{t}}=$ USA per Capita Real GDP / Malaysia per Capita Real GDP, Y $3 \mathrm{t}=$ Japan per Capita Real GNI / Malaysia per Capita Real GNI, $\mathrm{Y}_{4 \mathrm{t}}=$ Japan per Capita Real GDP / Malaysia per Capita Real GDP, $\mathrm{T}=\mathrm{A}$ deterministic trend, $\alpha=$ Constant, and $\varepsilon=$ Residual. 
This allows first to transform these equations onto Least Squares (NLS and ARMA) form. With these transformed equations a stability test, namely Chow Breakpoint Test was employed to ultimately identify the structural breaks using a single series of data set. With results from Chow's Breakpoint Test a recursive estimation, namely CUSUM Test was conducted in order to graphically view the structural breaks, if any, for the above three economies

\section{Results and Discussions}

In order to carry out Chow Breakpoint Test the entire time-series data were first divided into four sub-samples. Each sub-sample contained more observations than the number of coefficients in an individual equation resulting in the possibility to estimate that equation. The Chow Breakpoint Test, however, compares the sum of squared residuals obtained by fitting a single equation to the entire sample with the sum of squared residuals obtained when separated equations are fit to each sub-sample of the data. The overall transformation of the above equations, however, is called Modified ADF Test. As mentioned earlier the details of transformations of four equations and their resulting outcomes are presented below:

Transformed lag equation 5: lagJap_Mal_GDP=Jap_Mal_GDP-Jap_Mal_GDP(-1)

Transformed lag equation 6: lagJap_Mal_GNI=Jap_Mal_GNI-Jap_Mal_GNI(-1)

Transformed lag equation 7: lagUSA_Mal_GDP=USA_Mal_GDP-USA_Mal_GDP(-1)

Transformed lag equation 8: lagUSA_Mal_GNI=USA_Mal_GNI-USA_Mal_GNI(-1)

4.1 Explanations of Transformed Equation 1: Chow Breakpoint Test for Japan and Malaysia in Terms of GDP

From the following table we can see that F-statistic for the Chow Breakpoint Test is highly significant at $\mathrm{P}<0.01$ level, which simply means that both Japan and Malaysia have had experienced structural break/s in terms of GDP during the periods of 1980s, 1990s and 2000s.

Table 1: Chow Breakpoint Test Results for Japan and Malaysia in Terms of GDP.

\begin{tabular}{llll} 
Chow Breakpoint Test: 198019902000 & \\
\hline Null Hypothesis: No breaks at specified breakpoints & \\
Varying regressors: All equation variables & & \\
$\begin{array}{l}\text { Equation Sample: } 19712006 \\
\text { F-statistic }\end{array}$ & 8.925823 & Prob. F(6,28) & 0.0000 \\
Log likelihood ratio & 38.48660 & Prob. Chi-Square(6) & 0.0000 \\
Wald Statistic & 53.55494 & Prob. Chi-Square(6) & 0.0000 \\
\hline
\end{tabular}

4.2 Recursive Estimates (OLS Only) - CUSUM Test for Graphical Observation of the Structural Breaks between Japan and Malaysia in terms of GDP

Now in order for us to realize at which particular time/s the economies of both Japan and Malaysia have had experienced structural break/s we have conducted CUSUM Test. This test, however, reveals that both economies experienced a structural break in 1990s. 
Looking at the diagram below such a structural break can easily be detected in and around the year of 1997.

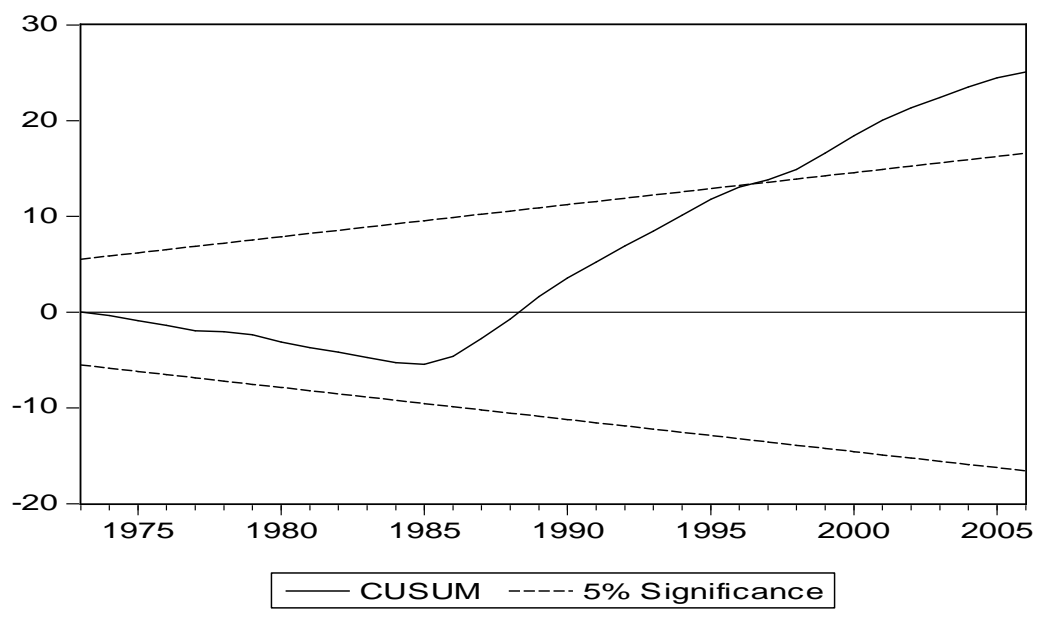

Figure 1: CUSUM Test Showing Possible Structural Break for Japan and Malaysia in Terms of GDP.

4.3 Explanations of Transformed Equation 2: Chow Breakpoint Test for Japan and Malaysia in Terms of GNI

From the following table we can see that F-statistic for the Chow Breakpoint Test is somewhat significant at $\mathrm{P}<0.05$ level, which simply means that the above two economies have had experienced structural break/s in terms of GNI during the periods of 1980s, 1990s and 2000s. If we just stick to the level of significance of $\mathrm{P}<0.01$ for realizing a strong structural break, we can accept the null hypothesis that the Chow Breakpoint Test has already generated in the following table. This just allows us to conclude that the both economies did not experience any strong structural break in terms of GNI during the above three periods.

Table 2: Chow Breakpoint Test Results for Japan and Malaysia in Terms of GNI.

Chow Breakpoint Test: 198019902000

Null Hypothesis: No breaks at specified breakpoints

Varying regressors: All equation variables

Equation Sample: 19712006

F-statistic 2.58258

Log likelihood ratio $\quad 15.85631$

Prob. F(6,28) $\quad 0.0405$

Wald Statistic

15.49551

Prob. Chi-Square(6)

0.0145

Prob. Chi-Square(6) $\quad 0.0167$ 
4.4 Recursive Estimates (OLS only) - CUSUM Test for Graphical Observation of the Structural Breaks between Japan and Malaysia in Terms of GNI

As mentioned earlier that both Japan and Malaysia did not experience any strong structural break in terms of GNI during the periods of 1980s, 1990s, and 2000s, such observation is already evident in the following figure. CUSUM Test has given evidence to the effect that both economies were close to experiencing a structural break only in 1980s. Looking at the diagram below such a likely structural break in terms of GNI was just close to affecting both Japan and Malaysia economies in and around the year of 1986.

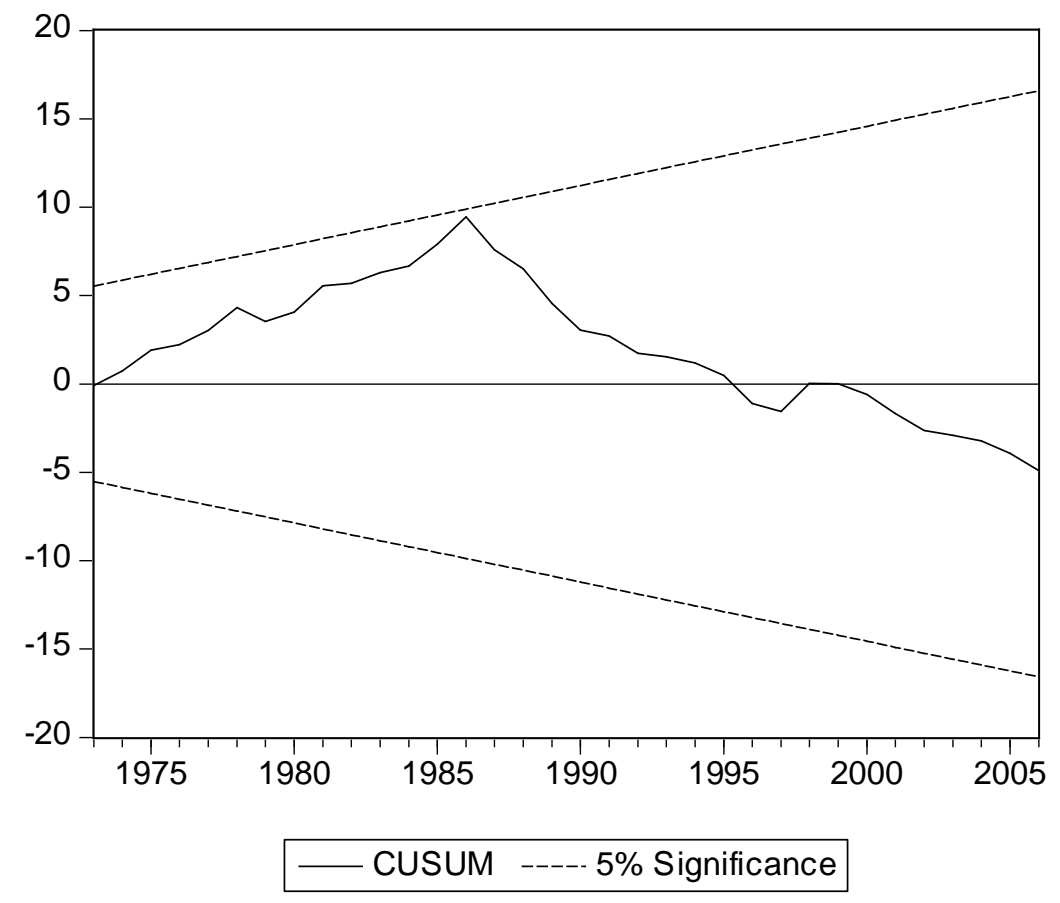

Figure 2: CUSUM Test Showing Possible Structural Break for Japan and Malaysia in Terms of GNI. 
4.5 Explanations of Transformed Equation 3: Chow Breakpoint Test for the USA and Malaysia in Terms of GDP

The following table shows that that F-statistic for Chow Breakpoint Test is not significant $(\mathrm{P}>0.05)$. So we can straightforwardly conclude that the USA and Malaysia did not experience any structural break in terms of GDP during the periods of 1980s, 1990s, and 2000s.

Table 3: Chow Breakpoint Test Results for the USA and Malaysia in Terms of GDP.

\begin{tabular}{llll}
\hline Chow Breakpoint Test: 198019902000 & & \\
\hline \multicolumn{4}{l}{ Null Hypothesis: No breaks at specified breakpoints } \\
\multicolumn{4}{l}{ Varying regressors: All equation variables } \\
Equation Sample: 19712006 & & \\
F-statistic & 1.922169 & Prob. F(6,28) & 0.1121 \\
Log likelihood ratio & 12.41754 & Prob. Chi-Square(6) & 0.0533 \\
Wald Statistic & 11.53301 & Prob. Chi-Square(6) & 0.0732 \\
\hline
\end{tabular}

4.6 Recursive Estimates (OLS Only) - CUSUM Test for Graphical Observation of the Structural Breaks between the USA and Malaysia in Terms of GDP

Since the USA and Malaysia economies have not had experienced any structural break in terms of GDP as already evidenced by Chow Breakpoint Test we can still depict the scenario in the following diagram. The recursive estimation as done by CUSUM Test shows clearly that GDP flow of the USA and Malaysia during the periods of 1980s, 1990s, and 2000s has had an up and down trend possibly at an increasing rate, but such trend has never reached either the extreme-upper frontier or the extreme-lower frontier of economic expansion or contraction of both countries. 
An Examination of Malaysia’s Structural Breaks

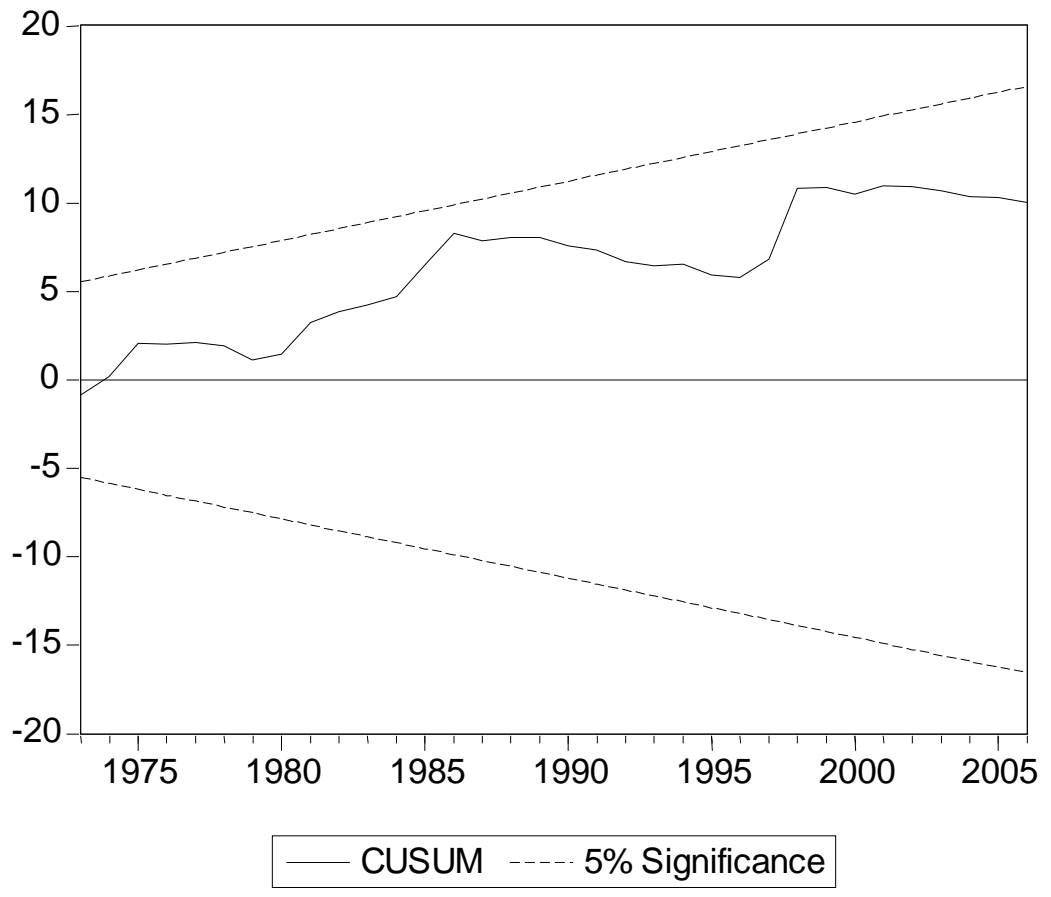

\section{Figure 3: CUSUM Test Showing Possible Structural Break for the USA and Malaysia in Terms of GDP.}

\subsection{Explanations of Transformed Equation 4: Chow Breakpoint Test for the USA and} Malaysia in Terms of GNI

The Chow Breakpoint Test was also run to determine any structural break/s, if any, for the economies of the USA and Malaysia in terms of their GNI. The F-statistics of the test, however, generated a probability value of 0.0968 , which is considered insignificant at $\mathrm{P}>0.05$ level. Since our empirical results obtained from Chow Breakpoint Test are subsequently compared with the ones we obtain from CUSUM Test, which considers a maximum of $5 \%$ significance, obtaining a significance at $\mathrm{P}>0.05$ level for F-statistic does not provide support to any strong and meaningful conclusion on structural break hypothesis. Therefore, we are accepting the Chow Breakpoint Test's null hypothesis that postulates that there have been observed no structural breaks for the USA and Malaysia in terms of GNI. 
Table 4: Chow Breakpoint Test Results for the USA and Malaysia in Terms of GNI.

Chow Breakpoint Test: 198019902000

Null Hypothesis: No breaks at specified breakpoints

Varying regressors: All equation variables

Equation Sample: 19712006

$\begin{array}{llll}\text { F-statistic } & 2.016632 & \text { Prob. } \mathrm{F}(6,28) & 0.0968\end{array}$

$\begin{array}{lll}\text { Log likelihood ratio } \quad 12.93000 \quad \text { Prob. Chi-Square(6) } & 0.0442\end{array}$

$\begin{array}{lll}\text { Wald Statistic } & 12.09979 \quad \text { Prob. Chi-Square(6) } & 0.0598\end{array}$

4.8 Recursive Estimates (OLS Only) - CUSUM Test for Graphical Observation of the Structural Breaks between the USA and Malaysia in Terms of GNI

The Chow Breakpoint Test has just proved that the economies of the USA and Malaysia did not experience any significant structural breaks during the periods of 1980s, 1990s, and 2000s, we have also found consistency of such result while compared it with the one we obtained from CUSUM Test. The following figure, as generated by CUSUM Test, clearly shows that GNI flow of the USA and Malaysia during the periods of 1980s, 1990s, and 2000s has had an up and down trend, as expected, possibly at an increasing rate, but such trend has never reached either the extreme-upper frontier or the extremelower frontier of economic expansion or contraction of both countries. 
An Examination of Malaysia's Structural Breaks

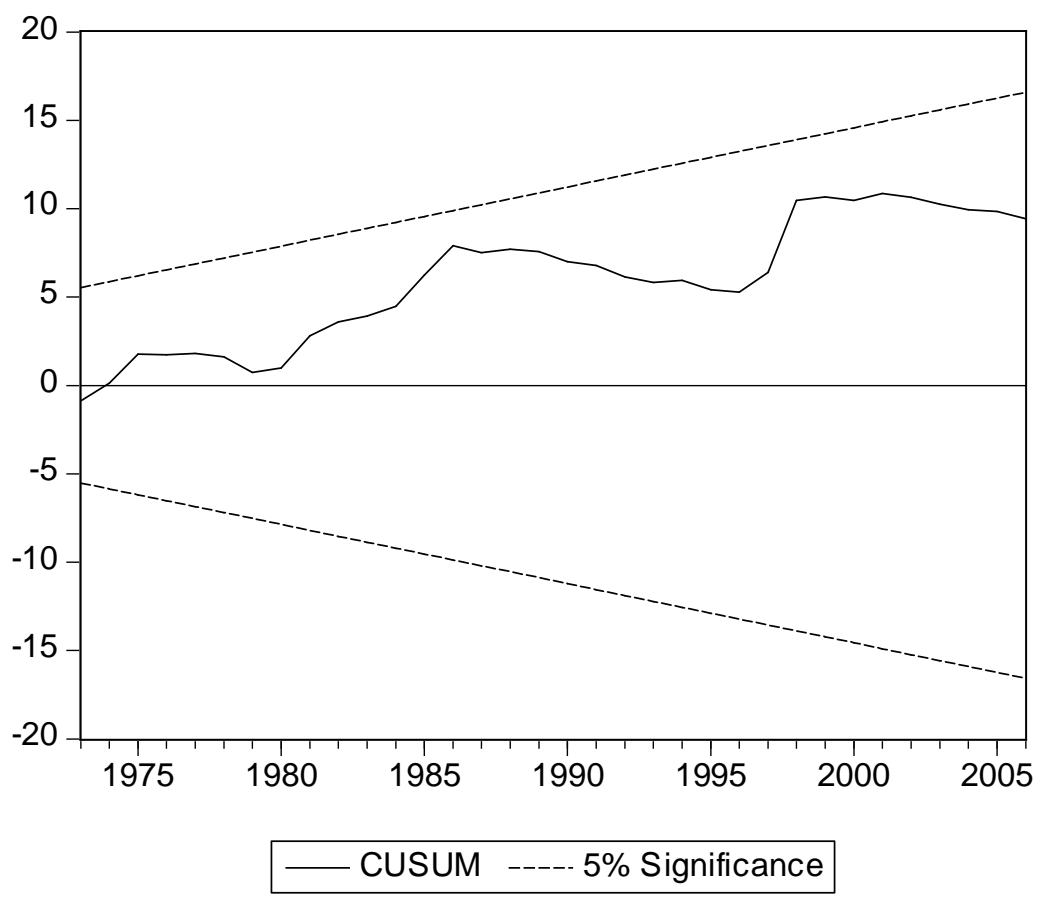

\section{Figure 4: CUSUM Test Showing Possible Structural Break for the USA and Malaysia in Terms of GNI.}

\section{Conclusion}

The Chow Breakpoint Tests reveal that only at $1 \%$ level of significance income ratio of Japan and Malaysia has had experienced structural breaks in terms of GDP during the periods 1980s, 1990s, and 2000s. But in respect of GNI, only at 5\% level of significance their income ratio has had experienced structural breaks during these periods. Income ratio of the USA and Malaysia does not have any structural break both in respect of GNI and GDP. That means Malaysia's income is diverging over time with incomes of the USA and Japan and therefore its income gaps with the above two countries have been widening. This may signify that Malaysia has been having unfavorable terms of trade with them and thereby has been sharing the benefits of globalization proportionately far less than its rich trading and growth partners. On the basis of the above income convergence and income ratio analyses it may reasonably be concluded that Malaysia's economic globalization has in fact failed to reduce its income gaps with the rich trading and growth partners. 


\section{References}

Index Mundi. (2009). Malaysia Unemployment rate. Malaysia. [Online] Available: http://www.indexmundi.com/malaysia/unemployment_rate.html (December 20, 2010).

International Labor Organization. (2003). 2003-2004 key indicators of the labor market. Geneva: ILO.

KOF Index of Globalization. (2009). 2009 KOF index of globalization. [Online] Available: http://globalization.kof.ethz.ch/static/pdf/rankings_2009.pdf (January 7, 2011).

Malaysia. (1996). Seventh Malaysia plan, 1996 - 2000. Putrajaya: Economic Planning Unit.

Malaysia. (2001). Eighth Malaysia plan, 2001-2005. Putrajaya: Economic Planning Unit. Malaysia. (2006). Ninth Malaysian plan, 2006-2010. Putrajaya: Economic Planning Unit.

Ming Yu, C. (2008). Malaysia: Moving towards Vision 2020. ACI Working Paper Series. Lee Kuan Yew School of Public Policy. National University of Singapore.

United Nations Industrial Development Organization. (2004). Annual report 2004.

Vienna: UNIDO. [Online] Available:

http://www.unido.org/fileadmin/import/37469_eannualreport (March 25, 2011).

UN Online Database. (2009). GNI at current prices - US dollars. [Online] Available: http://data.un.org/Data.aspx?d=SNAAMA\&f=grID\%3A103\%3BcurrID\%3AUSD\%3Bpc Flag\%3A0 (March 25, 2011).

World Economic Forum. (2008). The global competitiveness report 2008-2009. [Online] Available: http://www.weforum.org/pdf/GCR08/GCR08.pdf (March 21, 2011). 